\title{
Agnieszka Gralińska-Toborek
}

University of Łódź

Institute of Philosophy

Department of Ethics

ul. Lindleya $3 / 5$

90-131 Łódź

grala@filozof.uni.lodz.pl

\section{DUAL PLACE OF STREET ART - THE CITY VS THE INTERNET}

\begin{abstract}
Street art (or more broadly urban art), as the name suggests, has its own specific place, which is the street. ${ }^{1}$ However one would be mistaken to think that this type of art can only be seen there. Most street art lovers know the works of their favourite artists primarily through the Internet, not only because this kind of art is ephemeral or not easily accessible (for example, due to its dangerous or exotic locations), but because it is perhaps the best documented art that has been created in the world. For artists and lovers of street art, the Internet has become a common space to share photos. More often than not, the Internet also becomes the only place where artistic ideas exist. Paradoxically, such art, which was supposed to be the nearest to the viewer in the physical sense, has become the nearest in the virtual sense. One can, however, hope that neither consumers of art nor artists will have to give up their direct experience of art that builds our polysensory sensitivity.
\end{abstract}

\section{Keywords:}

Street art, graffiti, urban art, art in public space, art in Internet

\section{LOCAL ART}

The city, street and home are places whose nature keeps changing. Having one's own place once meant having roots somewhere or having somewhere to come back to. Hans Belting points out that in the past a place used to have an "established meaning via its residents. Its identity derived life from the history that

\footnotetext{
${ }^{1}$ The term "street art" is by far more popular than urban art, although there are authors who treat the latter term as superior, combining street art and graffiti - seen as a separate form, or as a term highlighting the illegality of these activities. See: Carlo McCormick, Marc \& Sara Schiller, Ethel Seno, Trespass. A History of Uncommissioned Urban Art (Köln: Taschen, 2010). In Poland, the term "street art" has been commonly adopted, see: Elżbieta Dymna, Marcin Rutkiewicz, Polski Street Art (Warszawa: Carta Blanca, 2010); Elżbieta Dymna, Marcin Rutkiewicz, Polski Street Art. Part 2. Między anarchiq a galeria (Warszawa: Carta Blanca, 2012). For the purpose of this paper, the term "street art" will be used.
} 
taken place there. Places possessed a self-contained system of signs, actions and images to which only locals had the key. Outsiders were just that, outsiders."2 Art - architecture, painting, decorations - which derived from a particular place to a large extent made this place stand out, made it "one and only in the world." Today places are losing their distinct and unique character. Following Belting's train of thought, it can be said that places "have become fragmented or undermined in such a way, that they cease to be distinguishable from other places, except perhaps as a metaphor (...). Something similar is happening to local cultures, which one can no longer encounter in their traditional places." ${ }^{3}$ And while large cities care about maintaining the image of their uniqueness, one should not harbour any illusions that localness intermingles with globalisation in these cities, as life in world metropolises does not differ much.

Street art, as art associated directly with the urban street, does not usually emphasize the localness of the place but rather competes with this place, exposing its own originality and making a given site important due to its own presence. This art can be seen as the fruit of the labour of contemporary nomads, artists, who are only temporarily connected with a given city, travelling the world and leaving their traces everywhere. ${ }^{4}$ Some well-known street art artists use the traditions from where they originated, although they do not preserve them in their original site, but disseminate these traditions in places where they cease to be understandable and readable. Some works are trademarks of the artists themselves more than elements of a particular culture: works of Inti (Inti Castro) ${ }^{5}$ - characterised by express Chilean iconography; Nunca (Francisco Silva) - bearing the aesthetic tradition of Brazilian Indians; Add Fuel (Diogo Machado) - replicating Portuguese azulejo tile patterns; or Nespoon (Elżbieta Dymna) - reproducing Polish lace. Their meaning for the recipient comes down to that of an ornament.

However, there are also artists who, without giving up their own recognisable style, seek to understand the places where they are, observe them and listen to the stories and the needs of their inhabitants. The popularity of such artists as eL Seed or JR best testifies to the need for art which is local and highlights problems of the community, but also reveals what is valuable in a given place. ${ }^{6} \mathrm{JR}$ photographs local inhabitants in many places of the world that

\footnotetext{
${ }^{2}$ Hans Belting, An Anthropology of Images: Picture, Medium, Body (Princeton, Oxford: Princeton University Press, 2011), 41.

${ }^{3}$ Ibidem, $40-41$.

${ }^{4}$ Hence, in the authors' biographical entries, the term "based in" is usually used.

${ }^{5}$ Not all the artists reveal their identity, that is why their names, if known, are given in parentheses.

${ }^{6}$ Artist known as eL Seed describes one of his projects in the following manner: "I decided I wanted to show the heritage of Tunisia, and took a road trip across the country to find its forgotten
} 
are - especially dangerous and neglected, and puts up on the walls of their homes large-format portraits. He has been to Brazilian slums, Palestine and Israel, and to African cities immersed in ethnic conflicts. "In the "Perception" project created in Cairo in Manshiyat Nasr, known as the "garbage district," eL Seed drew the attention of the entire world ${ }^{8}$ to the community of Copts, who though marginalised and isolated as "garbage pickers," created "the most efficient and highly profitable recycling system on the global level." ${ }^{\circ}$ On the walls of 50 buildings, eL Seed created an anamorphic work - a circle with an inscription in Arabic containing a quote of St. Athanasius of Alexandria: "Anyone who wants to see the sunlight clearly needs to wipe his eye first." 10

The need for local art is expressed by commissioning street art artists to create works about a particular topic. The work entitled "A River of Words from Barca to Bertolla" created by Opiemme in the framework of the project of revitalisation of two declining districts of Turin is an interesting example. The artist, also known as a street poet, filled the pavements between both places with a $7 \mathrm{~km}$-long stream of words relating to the topic of water. In the past, those were districts inhabited by washerwomen and boaters. ${ }^{11}$ In this way, the authorities are trying to revive degraded and neglected city areas.

Putting a great deal of hope in art which would "turn the world inside out,"12 especially the lives of actual people, may be asking too much. ${ }^{13}$ Nevertheless, making certain places stand out thanks to successful projects can attract the attention of the entire world to these sites due to the popularity of street art on the Internet.

history. I went from town to town, meeting people and asking them about the history of the place. Based on these conversations, I painted 24 walls in 17 cities over one month. From this, I made a book called 'Lost Walls'," Karen Eng, "The beauty of calligraphy, the power of street art: We watch eL Seed create 'calligraffiti'," TEDblog, August 21, 2015, http://blog.ted.com/el-seed-usescalligraffiti-to-transce nd-language/, accessed 22.09.2017.

${ }^{7}$ Projects: "Face to Face" 2007 and "Women are Heroes" 2008-2010. The documentation can be found on the author's website: http://www.jr-art.net/projects.

${ }^{8}$ The work received the UNESCO-Sarjah Prize for Arab Culture.

9 “@El Seed - Perception - Zaraeeb - Egypt”, http://elseed-art.com/, accessed 22.09.2017.

${ }^{10}$ The community of Zaraeeb consists mostly of Christians, St. Athanasius of Alexandria was a bishop in Egypt in the 4th century. The work of eL Seed is entirely visible from Mokattam Mountain, where St. Simon Monastery, carved in the rock, is situated.

${ }^{11}$ The photographic documentation can be found on: http://opiemme.com/en/river-words-artribune/.

12 "Use art to turn the world inside out" is the title of the lecture which JR delivered for TED viewers: https://www.youtube.com/watch? $=0$ PAylzBtTbw.

${ }^{13}$ The Herakut duo (Hera-Jasmin Siddiqu and Akut, Falk Lehmann) created a very meaningful mural that is an answer to such slogans. It shows a child with enormous, rebellious eyes writing the sentence: "Art doesn't help people. People help people." 


\section{HOT SPOT}

The place where street art appears does not need to be considered specific due to its history or its people. On the contrary, graffiti often "moves into" a space without an identity - nobody's space, abandoned, vandalised, and bland (see fig. 1,2). Sometimes it is just a random choice made by one artist, which attracts other artists. Graffiti and street art enjoy a dialogical relationship. This characteristic phenomenon is described in a book by Gary Shove: "I stumble across a flash of colour in an old doorway. It's like a shrine on the roadside. The whole thing is covered with intricate stencil work and over painted with numerous tags. It's a spot. Why here? How does a spot become a spot? It seems that there is a secret map of the city known only to the faithful. Artists repeatedly come back to the same places to both see each other's work and put up new work in the same place. It seems a bit tribal, a bit ritualistic. Sure, there must be practical concerns involved but that can't be the whole story."14 The reason for choosing a particular place may be its accessibility and lack of security (vacant flats, ruined factories, or walls in poor neighbourhoods), or its popularity and visibility, as well as the permission granted by its residents or local authorities (such as Shoreditch in London or various "graffiti halls of fame" in most large cities). What makes a place attractive is not a single, original work thematically or formally associated with the place, but a plethora of traces left by artists (see fig. $2,3)$. The site-specific character of this kind of art follows from the fact that, according to Ella Chmielewska: "it attaches itself parasitically to the particular site at the very moment it appears. (...) By taking place, graffiti designates its context by marking a spatial entity with the temporal dimensions of a personal trace. By taking place, it also makes itself public and thus vulnerable to the elements, exposed to a chance apprehension and intervention, and open to being written over." 15 This place, however, becomes attractive not because of itself, but due to its street art or graffiti. It turns into a hotspot where an artist should leave behind his or her work, or where a tourist should take a photo. One may say that such places are contrasting and competing with the "uniformisation of modern corporate aesthetics," come "tasty bites for consumption" in the process of their commercialisation or become subject to easy gentrification.

\footnotetext{
${ }^{14}$ Gary Shove, Untitled II. The Beautiful Renaissance: Street Art and Graffiti (Darlington: ProActif Communications, 2009), 43.

${ }^{15}$ Ella Chmielewska, "Writing on the ruins, or graffiti as a design gesture," in The Wall and the City il muro e la città, le mur et la ville, ed. Andrea Mubi Brighenti (Trento: Professional Dreamer, 2006), 44.

${ }^{16}$ Ibidem, 122.
} 


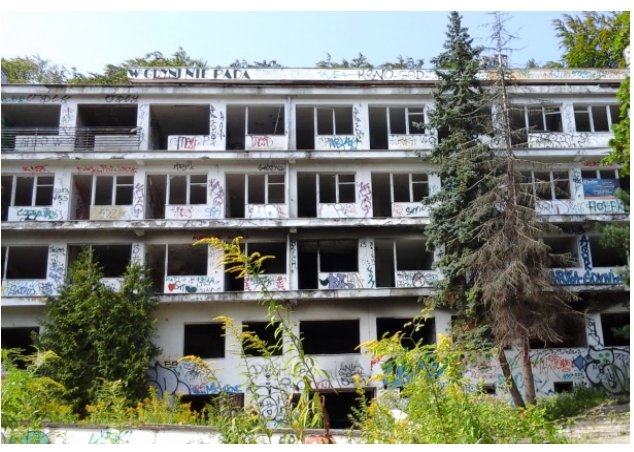

Fig. 1. Gdynia-Orłowo, 2017, abandoned sanatorium building. Photo by Wioletta Kazimierska-Jerzyk.

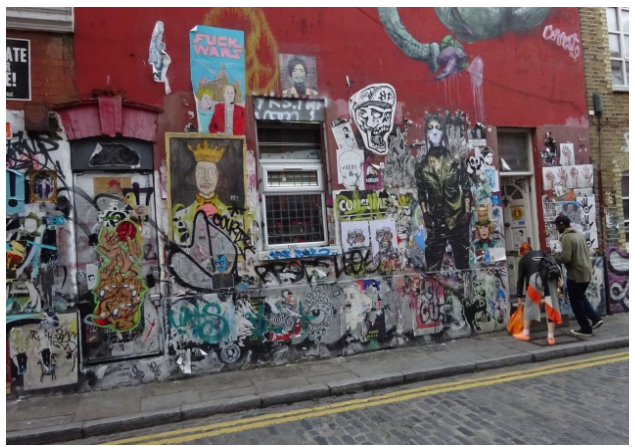

Fig. 3. The wall in Shoreditch, London, 2017. Photo by Agnieszka Gralińska-Toborek.

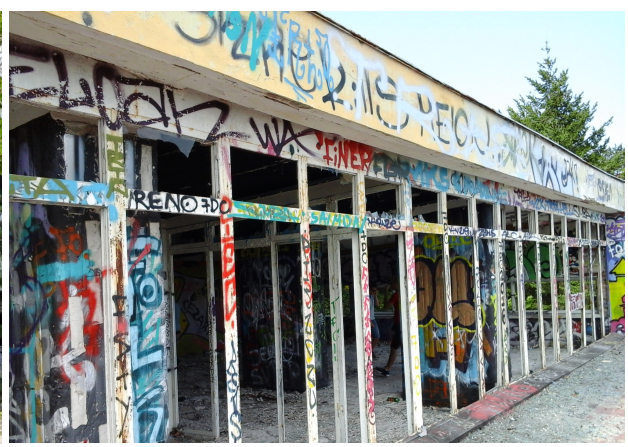

Fig. 2. Gdynia-Orłowo, 2017, abandoned sanatorium building. Photo by Wioletta Kazimierska-Jerzyk.

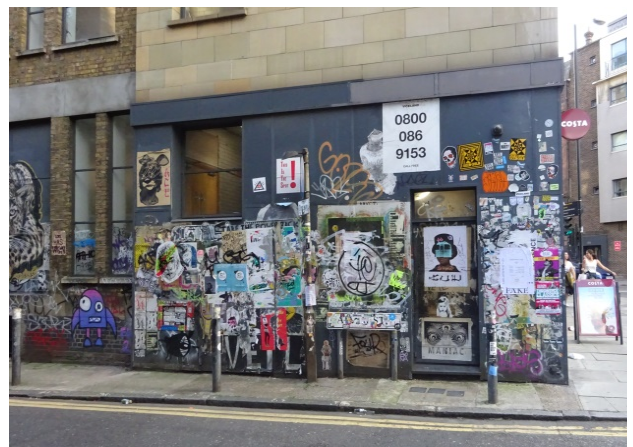

Fig. 4. The wall in Shoreditch, London, 2017. Photo by Agnieszka Gralińska-Toborek.

\section{A COLLECTION OF SITES AND IMAGES}

Places in the past were characterised by the presence of images belonging to the local cultural code. Contemporary places host images which do not arise from these localities and which bring whole new sets of values and levels of quality that change the meaning of their surroundings. Moreover, these images become for many recipients so important that they preserve the images in photographs, usually not taking into consideration the place of their existence and its identity. Up till now, people have created images of places or images of paintings (various kinds of copies).

Creating images of places, however, tends to result in making them unreal. Hans Belting points out that: "(...) Many places exist for us merely as images, in more or less the way we remember the places of the past. People have always remembered places as images, but that kind of image presupposed that one actually had been to the place. By contrast, today we know many places only in 
pictures, in which they taken on another kind of presence for us." ${ }^{17}$ A photo of a work of street art associated with a particular site loses the specificity of the work itself (its medium, size, or non-visual qualities) as well as of the place itself (which has its own spatial, polysensory, functional and temporal characteristics). One cannot see all this in a photo. The problem, however, lies not only in the fact that people reproduce, duplicate, and photograph the images that they have seen somewhere else, but that we know them only through this channel. As Belting says, people no longer visit various places physically, instead the places come to them in the form of images, people no longer watch "live art," just images of art. ${ }^{18}$ This phenomenon has its roots in the technological advancement of the turn of the $20^{\text {th }}$-century, and since then, as Walter Benjamin points out, art works have lost their aura, instead attracting mass consumers. There are certainly still enthusiasts 'hunting' for street art all over the globe. They are the authors of an extortionate number of photos of street art presented in photo albums or shown on the Internet. And there are no doubts that these photographs are mementoes of their authentic experience, documentation of what is seen and experienced in a specific, physical location. ${ }^{19}$ Once, however, they appear on the Internet, their value as mementoes disappears along with the disappearance of their authorship. The Web becomes an immeasurable collection what Umberto Eco calls "the Mother of All Lists" and describes as follows: "The Mother of all Lists, infinite by definition because it is in constant evolution, the World Wide Web, which is both web and labyrinth, not an ordered tree, and which of all infinities promises us the most mystical, almost totally virtual one, and really does offer us a catalogue of information that makes us feel wealthy and omnipotent, the only snag being that we do not know which of its elements refers to data from the real world and which does not. There is no longer any distinction between truth and error." ${ }^{20}$ On the Internet, their works are distributed, recorded, and reproduced, and sometimes it is the only place where these works exist. Many artists put on their websites or social networking sites photos of their unrealised or unfeasible projects, or jokes involving the proverbial "painting a moustache on a photo." 21

\footnotetext{
${ }^{17}$ Hans Belting, An Anthropology of Images, 40-41.

${ }^{18}$ Ibidem, 43.

${ }^{19}$ In the book entitled "Concrete canvas," many photos made by Lee Bofkin are accompanied by descriptions of daring feats that he was forced to perform to take good photos of a given work. Lee Bofkin, Concrete Canvas. How Street Art Is Changing the Way Our Cities Look (London: Cassel Illustrated, 2014).

${ }^{20}$ Umberto Eco, The Infinity of Lists: from Homer to Joyce (London: MacLehose, 2009), 360.

${ }^{21}$ Many such works are shown by Sandrine Estrade Boulett (http://sandrine-estrade-boulet.com) or OakOak http://www.oakoak.fr. Katja Glaser calls such works 'street art for the Internet,' i.e. "works that could have been realised in remote areas, in abandoned buildings, in one's own backyard or even at one's home. Additionally, some artists use their online channels to exclusively upload sketches, graphic or illustrations. In these cases, the notion of street art acts as nothing but
} 


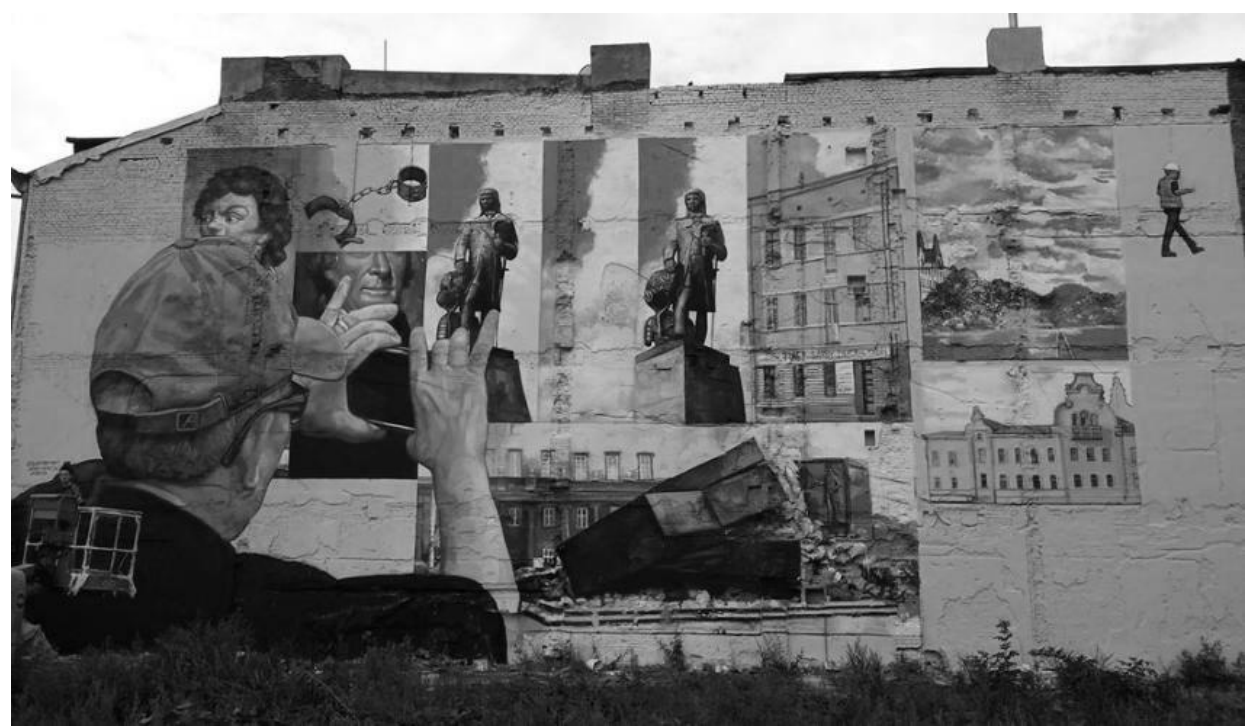

Fig. 5. Mural "Dementia" by Gaia, Łódź 2016. Source: Urban Forms Fundation, photo by Grzegorz Stężała.

\section{IN THE WEB OF CONNECTIONS}

The Internet is not, however, only a collection of amateur photos taken by lovers of street art. As Hela Zahar points out, even the type of camera used to take the photos indicates the kind of "image practice" and foretells the kind of site the photo will occupy on the Internet. ${ }^{22}$ Amateur photos taken with mobile phones become part of collections and appear on social networking sites (see fig. 6), while professional pictures are created for a different purpose (see fig. 7). The Internet is primarily a network of connections between artists and owners of

label. The fact is that both of these kinds of works do not necessarily need a 'street' to work as street art pieces, as long as they are documented and circulated adequately." Katja Glaser, "The 'Place to Be' for Street Art Nowadays is no Longer the Street, it's the Internet," Street Art \& Urban Creativity Scientific Journal 1, no. 2 (2015): 7.

${ }^{22}$ She states: "For instance, if digital image is captured by a digital SLR camera, stored on a computer and published on a web site, this constitutes a different practice than an image captured by a cellular phone and instantly circulated on Instagram. Image practices of street art scene are then seen as dynamic, physical, and digital. They are in a constant state of evolution, which reflects the changing nature of these visual scenes. These image practices are the centre around which gravitate participants, images(both physical and digital) and places (both physical and digital). Physical image practices and those that result in finished street-art pieces: digital images of street art works that circulate in various formats and digital locales," Hela Zahar, "Street Art: Visual Scenes and the Digital Circulation of Images," Street Art \& Urban Creativity Scientific Journal 2, no. 2 (2016): 43. 
portals and galleries, it is new "Art World" for street art. On the one hand, these are artists' home pages are where we see their portfolios along with their profiles on social networking sites that allow us to follow the step by step actions they take, their plans and projects, and additionally let us glimpse their personal lives and the "tricks" of their artistic trade. What is personal and what is public often blends there. On the other hand, we have blogs and portals run by "specialists" who hardly speak about art and seldom offer in-depth arguments, who do not analyse, assess, or criticise, sometimes just paste a few sentences from other portals, especially online editions of newspapers and magazines.

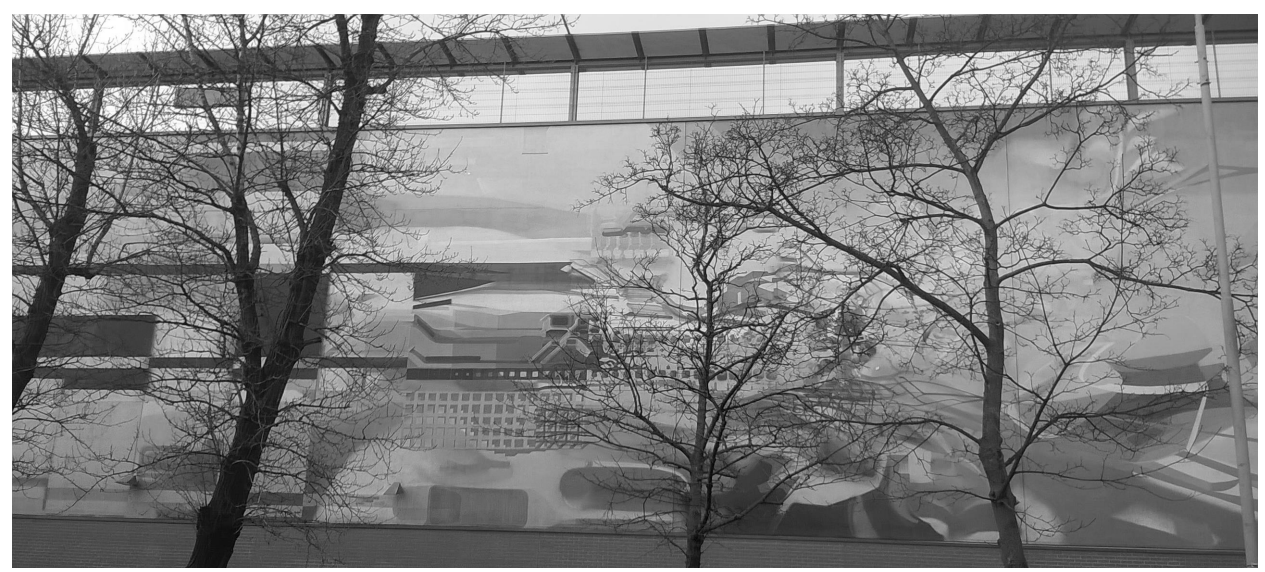

Fig. 6. Mural "Transition” by Proembrion (Krzysztof Syruć), Łódź 2013, amateur photo taken with a mobile phone. Photo by Agnieszka Gralińska-Toborek.

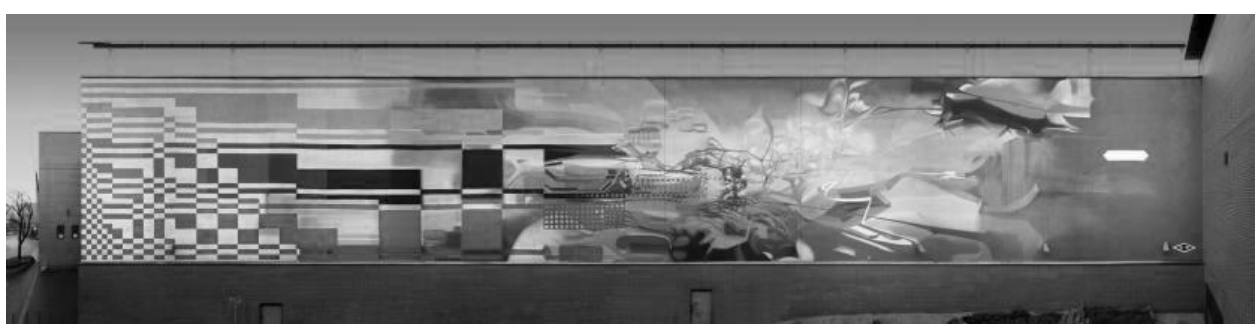

Fig. 7. The same mural, professional photo composed of many smaller photos. Source: Urban Forms Fundation, photo by Maciej Stempij.

Moreover, they do not describe the photos presented, do not provide the information required by most publications, such as the title of the work, the author's name and photo, the year when the work was created, or the technique and material used. Often, the information about sources is just an address of another website. A well-taken photograph is of paramount value here. Artists cooperate with professional photographers, sometimes the very process 
of creation is photographed or recorded. The selection is subjective and people who look at street art online remain under the influence of these subjective choices, their impression of a particular city is built only on what they have seen on the Internet. This, of course, also has an impact on art itself, as it is increasingly created to be presented on the Internet. Sometimes bloggers, photographers and festival organisers have a real influence on the appearance, size, and location of artists' works. ${ }^{23}$ According to Giada Pellicari, "These means are no longer seen simply as documentation for their own sake, for personal use or for fanzines, but more as visual memes to be exported within social networks and as a means of self-assertion and demonstration to the peer group of what they are capable of doing. It is worth noting, then, that through websites graffiti, which is by its nature ephemeral, is frozen and represented in this way as an eternal, digital present, consequently pre-empting their decline with the passage of time." ${ }^{24}$ Preserving graffiti and street art works on the Internet is therefore a method of popularising not physical places but rather works of art themselves, and even more so a method of building careers and legends of their creators. At the same time, publishing this "image documentation" on the Internet is a way of creating virtual sites for viewing art. The audience may no longer wish to see live works (a separate issue is whether the work still exists in the real world), and artists may no longer need to fight for the visually best space for their works, as they may even completely move into the virtual realm. ${ }^{25}$

\section{THE MEDIUM AND THE CONSEQUENCES OF ITS CHANGE}

W.J.T. Mitchell distinguishes two basic media models: the transmitter and the habitat. ${ }^{26}$ While showing the transfer of street art from walls and city streets to the Internet, a change of its site can be observed. This change would not have been possible, if not for the use of a new medium - i.e. the transmitter. In the real world, the media of street art are paint, paper, and various type of graphics, in the virtual world the media are digitised photos, films and finally the Web itself. Then, the remediation of works follows - which for the average consumer is only a method of distributing, preserving and documenting images. One cannot forget, however, that this process involves modification and adaptation

\footnotetext{
${ }^{23}$ Katja Glaser, "The 'Place to Be'," 9-10.

${ }^{24}$ Giada Pellicari, "Graffiti and New Media. The Correlations Between the Two Culture," in Lisbon Street Art \&Urban Creativity. 2014 International Conference, ed. Pedro Soares Neves, (Lisbon: Urbancreativity.org, 2014), 207.

${ }^{25}$ Katja Glaser, "The 'Place to Be'," 7.

${ }^{26}$ William John Thomas Mitchell, What Do Pictures Want?: The Lives and Loves of Images (Chicago, London: The University of Chicago Press, 2005), 208.
} 
of works as such, ${ }^{27}$ which means that the reception and aesthetic experience change, too, as it is the medium that to a large extent determines our perception. It is enough to imagine how we perceive a photo of a $60-\mathrm{m}^{2}$ mural on a mobile phone screen. And when on the same screen we see details of the image by sliding our finger across the slippery surface? These details are impossible to be seen by a viewer standing directly in front of the mural. A few-centimetre tall figures of Pablo Delgado stuck at the feet of pedestrians in London are more visible in the pictures on the Internet than in real life (and one does not have to bend down to see them). Moreover, media permeate one another and keep posing new reception challenges. Nowadays, while standing in front of a mural, it is possible to look at it at the same time by means of a phone application, or sit in front of a computer roaming the streets using google maps. As emphasised by Mitchell, the medium is a social practice, it is like a recipe consisting of many ingredients. ${ }^{28}$ This practice is creative as well as receptive. Artists design their work on the computer or on a piece of paper. Transplanted into the urban space, and, in the case of murals additionally enormously enlarged, these works change their character as well as meaning, and may often not satisfy their creators. Works seen first on the Internet and then "live" may surprise viewers and sometimes even disappoint. That is why some people remain in front of the screen out of convenience. ${ }^{29}$ Paradoxically, art, which used to seek a direct encounter with its audience, which used to be a clear trace of its author's presence, which was unprotected by any barriers and confronted directly with urban life has been suddenly transferred into the realm of unreality.

It would be a great loss to become deprived of the direct aesthetic experience arising from contact with the original work, which in the case of street art is still directly associated with its environment, if not in terms of content, at least physically. Rüdiger Bubner laments that "our well-informed aesthetic culture of the museum of our imagination feeds on second-hand food. The substitute nature of the influence of that which is known only from reproduction reveals itself in the shock that we experience in every true confrontation with an image. $"{ }^{30}$ One may hope, therefore, that artists and art consumers will not give up this corporal, polysensory adventure of encountering by substituting it with the easy and safe visual pleasure of sliding their finger on the surface of a screen. How rousing the words of the book "Untitled II" sound: "We could

\footnotetext{
${ }^{27}$ Kamila Tuszyńska, Narracja w opowieści graficznej (Warszawa: PWN, 2015) 378-379.

${ }^{28}$ William John Thomas Mitchell, “There Are no Visual media,” Journal of Visual Culture 4 (2) (2005): 261, http://journals.sagepub.com/doi/pdf/10.1177/1470412905054673.

${ }^{29}$ It is worth noting that the main attribute of graffiti and street art used to be a can of spray paint. It was the most common "iconographic motif" of street art. Nowadays urban images more often depict smartphones or other screens.

${ }^{30}$ Rüdiger Bubner, Doświadczenie estetyczne, trans. Krystyna Krzemieniowa (Warszawa: Oficyna Naukowa, 2005), 71.
} 
blog street-art till our fingers bled but it would never have the same power as when you stumbled upon that piece hidden in a shop doorway while you stopped to answer the call of nature after missing the last bus home. You can stick your work up on Deviant Art and, yes, there is some amazing stuff up there but it will never be enough. Real hands making work out in the streets is a powerful magic but replace it? No. Evolve it? Hell, yes."

Translated by Marta Koniarek

\section{BIBLIOGRAPHY}

Belting Hans, An Anthropology of Images: Picture, Medium, Body. Princeton, Oxford: Princeton University Press, 2011.

Bofkin, Lee. Concrete Canvas. How Street Art Is Changing the Way Our Cities Look. London: Cassel Illustrated, 2014.

Chmielewska, Ella. "Writing on the ruins, or graffiti as a design gesture." In The Wall and The City il muro e la città, le mur et la ville, edited by Andrea Mubi Brighenti, 31-45. Trento: Professional Dreamer, 2006.

Dymna, Elżbieta and Marcin Rutkiewicz, Polski Street Art, Warszawa: Carta Blanca, 2010.

—., Polski Street Art. Part 2. Między anarchiq a galeria, Warszawa: Carta Blanca, 2012.

Eco, Umberto. The Infinity of Lists: from Homer to Joyce. London: MacLehose, 2009.

Eng, Karen. "The Beauty Of Calligraphy, the Power of Street Art: We Watch eL Seed Create 'Calligraffiti'." TEDblog, August 21, 2015, http://blog.ted.com/el-seed-uses-calligraffiti-totranscend-language/ accessed 22.09.2017.

Glaser, Katja. "The 'Place to Be' for Street Art Nowadays is no Longer the Street, it's the Internet." Street Art \& Urban Creativity Scientific Journal 1, no. 2 (2015): 6-13.

McCormick, Carlo and Marc Schiller and Sara Schiller and Ethel Seno. Trespass. A History of Uncommissioned Urban Art. Köln: Taschen, 2010.

Mitchell, William John Thomas. What Do Pictures Want?: The Lives and Loves of Images, Chicago. London: The University of Chicago Press, 2005.

— “There Are no Visual media," Journal of Visual Culture 4 (2) (2005): 257-266. http://journals.sagepub.com/doi/pdf/10.1177/1470412905054673.

Pellicari, Giada. "Graffiti and New Media. The Correlations Between the Two Culture." In Lisbon Street Art \&Urban Creativity. 2014 International Conference, edited by Pedro Soares Neves, 198-204. Lisbon: Urbancreativity.org, 2014.

Shove, Gary. Untitled II. The Beautiful Renaissance: Street Art and Graffiti. Darlington: Pro-Actif Communications, 2009.

Tuszyńska, Kamila. Narracja w opowieści graficznej. Warszawa: PWN, 2015.

Zahar, Hela. "Street Art: Visual scenes and the digital circulation of images." Street Art \& Urban Creativity Scientific Journal 2, no. 2 (2016): 42-44.

${ }^{31}$ Gary Shove, Untitled II, 168. 